\title{
Strengthening the Existence of Islamic Education in the Industrial Revolution Era 4.0
}

\author{
${ }^{1}$ Noor Amirudin*, ${ }^{2}$ Mohammad Ahyan Yusuf Sya'bani, ${ }^{3}$ Triyo Supriyatno, ${ }^{4}$ Samsul Susilaw ati \\ ${ }^{1}$ Student of an Islamic Religious Education Doctoral Program Based on Interdisciplinary Studies-UIN Maulana Malik Ibrahim \\ Malang, Indonesia \\ Email: 200101310004 [AT] student.uin-malang.ac.id \\ ${ }^{2}$ Student of an Islamic Religious Education Doctoral Program Based on Interdisciplinary Studies-UIN Maulana Malik Ibrahim \\ Malang, Indonesia \\ Email: 200101310003 [AT] student.uin-malang.ac.id \\ ${ }^{3}$ FIT K-UIN Maulana Malik Ibrahim \\ Malang, Indonesia \\ Email: triyo [AT] pai.uin-malang.ac.id \\ ${ }^{4}$ FIT K-UIN Maulana Malik Ibrahim \\ Malang, Indonesia \\ Email: susilawati [AT] pips.uin-malang.ac.id
}

\begin{abstract}
----
Purpose: This study provides an overview of the importance of massive reform in the Curriculum of Islamic Education at the Faculty of Islam, University of Muhammadiyah Gresik. This reform is needed so that the Islamic education curriculum can answer the challenges and demands of the times that continue to change globally. Besides, this deafness also poured out the results of a solution to Islamic religious education in the face of the Era of Industrial Revolution 4.0.

Method: this type of research is a type of field research. To obtain the data of this study used the observation method, interviews, and documentation. The research was analyzed with descriptive qualitative. To analyze the factors that influence the internalization of Islamic values, reduction analysis, data presentation and verification are used.

Findings: The era of the Industrial Revolution 4.0 had a broad impact on all lines of life, including in the field of education, especially Islamic education. The era that gave birth to this disruption phenomenon demanded the world of Islamic religious education to participate in adjusting. Graduates of Islamic education are now faced with new challenges, demands, and needs that have never existed before. So it is necessary to update and innovate the system, governance, curriculum, human resource competencies, facilities and infrastructure, culture, work ethic, and others.

Implications for Researh and practice: Islamic religious education will be increasingly left behind and outdated. Therefore, it is necessary to look for concrete steps for Islamic religious education in order to be able to remain competitive in this disruption era.
\end{abstract}

Keywords--- Is lamic education, industrial revolution 4.0, disruption

\section{INTRODUCTION}

Along with the times, the challenges and obstacles of Islamic religious education also continue to experience development and change. If in the past few decades intimate conversations between students and teachers have been taboo, then today is a natural thing. Even in the view of modern education theory, it is a necessity. Such interaction is an indication of the success of the education process.

Another paradigm shift for example in terms of learning approaches. In the era of traditional Islamic religious education, teachers became a centralfigure in learning activities. It is the primary source of knowledge in the clas sroom, even the only one. However, in the context of modern Is lamic religious education, such case is no longer valid. The role of today's teachers has undergone a shift, namely as a facilitator for students. Learning is no longer teacher-centered (teacher centered), but more student-centered.

Shifts and changes as described above are a certain inevitability. This is due from time to time social demands and needs continue to change. Today, extensive knowledge alone cannot guarantee that a graduate can speak much in global 
competition. Specific expertise is also needed that is in line with the needs of the field. If this is not the case, grad uates of education will be crushed and excluded. Moreover, now the world has entered a new era, namely the Era of the Indu strial Revolution 4.0.

The era of Industrial Revolution 4.0 (from now on: Era 4.0) has an unimportant impact. It affects all as pects of human life. Included in this case is education. This era is characterized by the increasingly central role of cyber technology in human life. So do not be surprised if in the world of education the term "Education 4.0" appears.

Education 4.0 (Education 4.0) is a general term used by education experts to describe various ways to integrate cyber technology both physically and not into learning. This is a leap from 3.0 education which according to Jeff Borden includes meeting neuroscience, cognitive psychology, and educational technology. Education 4.0 is a phenomenon that responds to the need for a fourth industrial revolution in which humans and machines are aligned to find solutions, solve problems and of course dis cover the possibility of innovations. https://eduaksi.com/pendidikan-4-0-apa/

Then how is Is lamic religious education facing this revolution? How does he take advantage of the opportunities that exist and at the same time ans wer the challenges and overcome obstacles that are not simple? This paper seeks to portray the dynamics of Islamic education curriculum review studies in Era 4.0 and map the strength, weakness, opportunity, and threat (SWOT).

\subsection{Islamic Education}

\section{LITERATURE REVIEW}

At least two meanings can be derived from the terminology of Islamic Education. First, education about Islam, secondary education according to Islam. The first terminology is more to regard Islam as a subject matter in education, while the second terminology places Islammore as a perspective in Is lamic Education (Djazaman, 2009, pp. 90).

Muhammad Hamid An-Nashir and Gullah Abdul Qadir Darwis define Is lamic education as a process of directing human development in terms of body, mind, language, behavior, and religious, social life which is directed towards goodness towards perfection (Muhroqib, 2009, pp. 17). Meanwhile Omar Muhammad At-Taumi Ash-Syaibani was quoted as saying by M.Arifin, stated that Is lamic education is an effort to changeindividual behavior in private life or community life and life in the surrounding environment (Amirudin, 2018, pp. 15).

Honestly, it must be admitted that Islamic religious education has been widely understood in the first sense, so the concept of Islamic religious education is more oriented to the material, curriculum and methods of how a teacher delivers Is lamic religious education material to students. If the Is lamic education is understood in the first sense, then the process that occurs is the transfer of Islamic values (Transfer of Islamic values) from the old generation to the younger generation without having to create conditions that make students think creatively and progressively.

If the second concept understands the notion of Is lamic religious education, then it will not view Islam as a set of values that are part of the education systembut view education as a process that is part of the Islamic life system(Djazman, 2009, pp.91). Therefore, it means that Is lam is not a subject that mustbe taught to students, but Is lamis more the soul of education its elf. Thus, Islammeans having concepts about education.

Islamic education is an attempt by cautious Muslim adults to consciously direct and guide the growth and development of fitrah (basic abilities) of students through Is lamic teachings towards the maximum point of growth and development (Arifin, 2003, pp.22). Education theoretically contains the meaning of "feeding" (opvoeding) to the soul of students so that they get s piritual satisfaction, als o often interpreted by "growing" basic human abilities. If you want to be directed towards growth following Islamic teachings, you must proceed through the Islamic religious education system both through in stitutions and through the curricular system (Amirudin, 2020, pp. 2690). The essence of electric potential in every human being lies in the faith or belief, science, morality, and experience (A l-Djamali, 1967, pp. 85). These four essential potentials become functional levels of Is lamic Education.

\subsection{The Purpose of Islmaic Education}

In general, Is lamic religious education aims to "increase the faith, understanding, appreciation, and experience of students about Is lam, so that they become Muslimhuman beings who believe and fear Allah SWT and have noble deeds in pers onal life, community, nation, and state (Muhaiman, 2004, pp. 78).

From these objectives, several dimensions can be drawn that are intended to be improved and aimed at learning activities of Is lamic religious education, namely: a) the dimensions of the faith of students in the teachings of Is lam b) dimensions of understanding or reas oning (intellectual) and scientific learning of students towards the teachings of Is lams c) dimensions of appreciation or inner experience felt by students in carrying out Islamic teachings; and d) the dimensions of his experience, in the sense of how Islamic teachings that have been believed, understood and biological or internalized by students are able to foster motivation in him to move, practice, and wait for the teachings of religion and values in personal life, as believing human beings and fear Allah SWT and actualize and realize it in the life of society, nation and state.

In line with the description above, Athiyah al-Abrasyi revealed that there are five primary goals of Islamic education. First, it forms a noble character. According to him the formation of noble character is the spirit of Islamic education. This is in harmony with the primary purpose of sending the Prophet to this world, namely to perfect human morals. Second, provision of life in the world and the hereafter. Islamic religious education not only giving attention in 
religious terms, nor was the merely mundane. Is lamic education provides equal attention to both. Third, grow scientific spirit and satisfy taste want to know (curiosity). Fourth, prepare students in terms of professional, technical and company so that he can master certain professions, so that he can seek sustenance in life and life with dignity. Fifth, preparation for sustenance and maintenance of facets of benefit. As stated earlier, Islamic education does not only focus on moral formation but als o aims to provide knowledge of the world to students. The provision is in the formof specific skills thatcan be used by students to participate in competing in life (Zuhairini, 2015, pp. 64-66).

\subsection{Problems with Islamic Education}

The fundamental problemin education in Indonesia is the low quality of education. This is indicated, with the still high imbalance in the quality of education between regions. Indicators of education development at the provincial level show two trends, namely in the category above the national standard and below the national standard (Dwiningrum, 2011, pp. 289). Indicators of edu cation quality can be seen from participation rates, dropout rates, repetition rates, teacher-student ratios, school-teachers, teacher eligibility rates, and conditions for school infrastructure. This educational quality gap is multidimensional. Based on the phenomenon that continues to develop at this time, there are at least three main reasons, namely: First, education undergoes a process of reducing meaning, even degraded only memorizing activities and skills in working on exam questions (UN). Second, education falls into the process of commercialization, where education has turned into a commodity that is traded or traded and managed, like the industrial world which tends to be profit -oriented (profit oriented). Third, education only gives birth to the superiority of schools, namely schools becoming more powerful, dis tant, and pressing on parents of s tudents, both subtly, and openly (Dwiningrum, 2011, pp. 295).

Is lamic education in its existence as a component of nation-building, especially in Indonesia, plays a huge role and this has been going on long before the independence of the Indonesian nation. This can be seen in the practice of Islamic religious education organized by Muslims through traditional educational institutions such as majelis taklim, pengajian forum, surau and pesantren which thrive and exist until now (Arifi, 2010, pp. 2).

As with national education, Is lamic education in Indonesia is also being plagued by tiring problems. Because Islamic education is a national education subsystem, then when national education is considered a failure because there are still many problems that have not been successfully resolved it must be admitted that it is also a failure of Is lamic education. If you pay closeattention, Is lamic education in the middle of the day is faced with internal and external problems.

Internal problems can be seen in the ethos of Is lamic education today seen from the Is lamic school education system that is managed, such as Islamic boarding schools, Islamic schools, and Islamic colleges (UIN/IA IN/STAIN, PTAIS, etc.) are actually quite encouraging, or even if not, the number exceeding the need for overproduction, while other sciences oriented to science and technology are still scarce. So it is logical if there is an assumption that states, "Islamic students are poor about insight, mastery of science and technology, communication, and also politics." It is not wro ng to conclude that the ethos of Islamic education as it is today is stillnot paying attention to the link andmatchin building its education system(Barizi, 2011, PP. 7).

Syamsul Ma'arif stated that Is lamic education at this time was indeed in a deplorable and alarming condition. Islamic education experienced a deterioration far behind with Western education. If you may be a little nostalgic, Is lamic education cannot be like in the golden age (Andalusia and Baghdad) which could become the center of Is lamic civilization, both in the fields of culture, art or education. What happened was just the different, Is lamic education now followed and was oriented towards the West. With the supremacy of knowledge controlled by developed countries, Muslim countries continue to depend on the West in almost all lives: defense and weaponry, communication and information, economics, trade, education, and scientific development (Ma'arif, 2007, PP. 1-2).

This is a shamefulirony given the vastness of the Quranic concept of education. The lag can be seen fromat least the exis tence of madrasa and pesantren which used to have a strategic role in delivering the development of Indonesian society, now the enthusiasm of the community to enter madras a and pesantren education (es pecially those still mumbling with the "salaf" system) has decreased dramatically. Except for boarding schools (modern), that can adapt to global development. The public's pessimis m towards madrasa education and Is lamic boarding schools can be seen from the univers al concern about the ability of graduates to enter new jobs that are only open to those who have skills and mas tery of technology (Barizi, 2011, PP. 5).

While the external problems faced by Is lamic religious education are in the form of various advanc es in science and technology which have resulted in the emergence of scientific critique of traditional, textual, conserv ative and ritualistic religious explanations. The era of globalization in the field of information and socio-economic and cultural changes with all its effects. Included among them is the 4.0 industrial revolution which will be explained in the following description. Another challenge is the plurality of religious communities that are still not ready to differ in understanding and instead behave fanatically absolutist, apologists and truth claims are wrapped up with personal interest nodes or those that are political or sociological.

\section{Research Design}

\section{METHOD}

This type of research, when viewed in terms of the place of research, is including field res earch, namely res earch that aims to describe the state or status of a phenomenon. Therefore, information on research objects will be more widely found in the field where the res earch object is located (Koentjaraningrat, 1989,pp. 29). 
The approach used in carrying out this research is a qualitative descriptive approach, this method is es sentially observing people in everyday life in natural situations, interacting with them, conducting interviews and trying to make sense of language, ability and behaviour related to the focus of res earch (Moleong, 1993,pp. 31)

The above conditions cause researchers involved in the life of the research subject to a demand that can not be avoided. Affirmed by that in involving themselves in the lives of research subjects (informants), researchers will be able to establish close relationships with informants, conduct in-depth interviews with well and understand the subject with a natural setting.

\section{Determination of Research Subjects}

The method of determining the subject that the author uses is theSnowball Method which is looking for data such as a rolled snowball, meaning in determining the subject chosen key informant (a person who is considered to know a lot of the problems studied) then only to other informants (Muhadjir, 1996, pp. 134). This reformis needed so that the Is lamic education curriculumcan answer the challenges and demands of the times that continue to changeglobally.

\section{Data Collection Techniques}

Data collection techniques in this research/service use several methods, namely the method of observation, interviews, documentation, and tests. The use of this method is adjusted to the data needed (Hadi, 1989, pp. 136).

\section{Data Analysis Method}

According to Patton, the method of data analysis is the process of arrang ing data, organizing it into a pattem, category and one basic description. To be able to manage while producing a basic description analysis methods are used in accordance with the characteristics of a qualitative approach, the method of data analys is is carried out from the beginning, and developed during the data collection process until the process of preparing the report (Moleong, 1996, pp. 280).

\section{RESULTS}

The Era of The Industrial Revolution 4.0. The industrial revolution consists of two (2) words namely revolution and industry. Revolution, in the Great Indonesian Language Dictionary (KBBI), means that changes are very fast, while the notion of the industry is an effort to carry out the production process. So if two (2) words are combined meaningfully a change in the production process that takes place quickly. This rapid change is not only aimed at increasing the goods produced (quantity), but also improving the quality of production (quality).

The term "Industrial Revolution" was introduced by Frie drich Engels and Louis-Auguste Blanqui in the mid-19th century. This industrial revolution is also running from time to time. The last decade has been called entering the fourth phase 4.0. Changes in phase to phase give articulatory differences in terms of their use. The first phase (1.0) is concemed with the discovery of machines that emphasize ( stressing ) the mechanization of production. The second phase (2.0) has moved on to an integrated mass production stage with quality control and standardization. The third phase (3.0) enters the stage of mass uniformity which relies on computerized in tegration. The fourth phase (4.0) has presented digitalization and automation of the integration of the internet with manufacturing (Su wardana, 2017, pp. 102-110).

The fruit of the 4.0 industrial revolution is the emergence of a disruptive phenomenon innovation. Theimpact of this phenomenon has spread in all areas of life. Starting from industry, economy, education, politics, and so on. This phenomenon has also succeeded in shifting the lifestyle (lifestyle) and mindset (mindset) of the world community. Simple dis ruptive innovation can be interpreted as a phenomenon of dis ruption of incumbent actors by new industry players due to the ease of information technology.

One of the many examples around us is the declining income of motorcycle taxidrivers and taxi companies. This decrease in income was not caused by a decrease in thenumber of motorcy cle taxi and taxi users, buta change in consumer behavior. Thanks to the advancement of information technology, new transportation companies have emerged, such as GO-JEK, GRAB, and UBER, whose services are based on Android. Consumers only need to in stall the application on their smartphone to use their services. Besides, the tariff installed is also much cheaper. These three new players caused the neces sary transportation services to suffer losses.

Besides, the phenomenon of disruptive innovation also caused several professions to disappear because machines replaced them. For example, now all the work of the check-in counter staff at various international airports has been taken over by machines that can directly answer passenger needs, including scans to check passports and vis as, and printers to print boarding passes and luggage tags (Kas ali, 2017, pp. 16). Another impact is the emergence of new professions none before, like Youtuber, Website Developer, Blogger, Game Developer and so on.

The advantages of the emergence of disruptive innovation provide, among others: First, the convenience of consumers in meeting their needs. By cutting costs incurred, companies that use the latest technology can reduce costs so they can set prices far lower than incumbent companies. Thus, the cheaper the costs incurred by consumers make consumers more prosperous.

Second, a technology that makes it easy. The emergence of new innovations, of course, will bring new and sophisticated technology, at least compared to existing technology. Thus it can be said that there is a technology transfer 
towards a more modern one. Third, spur innovation-based competition. Indonesia is a country that cannot just prosper without innovation. With the exis tence of disruptive innovations, companies in the industry are forced to innovate so that they continue to improve their services.

Fourth, reducing the number of unemployed. The innovation will be done to provide new employment opportunities. If you do not open a new field, you can at least expand your existing employment. Es pecially with innovation, it can provide new employment opportunities with better wages than fromexis ting jobs. Fifth, increase economic growth. Dis ruptive technology following Schumpeter's theory will increase productivity due to efficiency. With these two things, it will increase the quality and quantity of goods produced. On the other hand, innovation will also increase public cons umption after previously his income increased. The development which is the endpoint is the increasing number of Gross Domestic Product. If every innovation can produce greater added value and relatively survive every year, it will increase economic growth in the long run.

Welcoming 4.0 Islamic Education. The industrial revolution 4.0 with its disruptive innovation put Islamic education at a crossroads. The intersection has its implications. Is lamic education is free to choose from. If he chooses the intersection of the pattern and sticks with the old system, then he must be willing and legowo when getting left behind. Conversely, if he opened himself, would accept the era of dis ruption with all the consequences, then he would be able to compete with others.

Referring to the results of a study fromMcKinsey in 2016 that the impact of digital technology towards the 4.0 industrial revolution in the next five (5) years there will be 52.6 million types of work will experience a shift or dis appear from the face of the earth. The results of this study give the mes sage that every self who still wants to have self-exis tence in global competition must prepare mentally and skills that have a competitive advantage fromothers. The primary way to prepare the most natural skills to take is to have good behavior (behavioral attitude), increase self-competence and havea literacy spirit. Provision of self-preparation can be passed with the education path (long life education) and self-concept through the experience of working across generations/across disciplines (experience is the best teacher) (Suwardana, 2017, pp. 102-110).

Based on these facts, it is necessary to reform or reform within the body of Is lamic education. Is lamic education in the era of 4.0 needs to participate in disrupting itself if it wants to strengthen its existence. Self-dis ruption means adjusting to the needs and demands of society and being oriented in the future. Muhadjir Efendy in his speech said that there needs to be school reform, capacity building and teacher professionalis $\mathrm{m}$, a dynamic curriculum, reliable facilities and infrastructure, and the latest learning technology so that the world of national education can adjust to the dynamics of the times.

The lag of Islamic education so far, in addition to being caused by problems as described earlier, was also caused by potential problems that did not meet the estuary. Rosidin (2006, pp. 186), revealed that four factors were causing Islamic education to get sharp criticis moften. First, cultural lag or cultural gap. This is due to the imbalance between the speed of development of science and technology and the s peed of development of education. The pace of acceleration of the development of science and technology is not accompanied by efforts to Is lamic education to participate in accelerating. As a result, Is lamic education is less responsive to the dynamics of social change in society. So that it becomes a necessity if the educational process in it becomes les s contextual.

Second, second class stigma. This second factor can be said to be a result indirectly from the first factor. The slowness of Is lamic education in responding to the dynamics of the development of science and technology and social reality caus ed the stigma of comfortable second class embedded in it.

Third, science dichotomy. Until now the dichotomy between Islamic science with general science (Sc ience, Social Sciences, Language-Humanities) is still a homework for Is lamic education. Although there have been many integration efforts between the two, but have not shown significant results.

Fourth, political dualism. Withdrawal of interests between the two institutions Education policymakers in this country often creates polemics among the grass root. Des pite many protests and complaints filed, but there is no standard solution to this problem. The policy differences between the Ministry of Education and Culture (Kemendikbud) and the Minis try of Religion (Ministry of Religion) often trigger polemics. Problems regarding salaries, certification, educator incentives and so on are examples of this factor.

In order to meet Is lamic Education 4.0, then inevitably all the potential problems above must be able to find a solution. If not, it will be difficult - if it is reluctant to say it is impos sible - realizing contextual Is lamic education towards the times. Therefore, as stated above, there needs to be reform and renewal of all aspects of Is lamic education. Borrowing the term Rhenald Kasali, there are three steps that Is lamic education must take in this era 4.0, namely disruptive mindset, self-driving, and reshape or create.

Disruptive mindset. Mindset is how humans think that determined by the settings we make before thinking and acting (Kasali, 2017, pp. 305). Is lamic education today is in a fast-paced digital age, high mobility, access to information is everyone's primary need. Besides that, today's society demands immediate and real-time. Everything needed must be immediately available. If access to these needs takes too long, the community will leave and move to other services. In es sence, the demand in this disruption era is a response.

Response speed will significantly affect the $u$ ser. This is called Rhenald Kasali as a corporate mindset (corporate mindset). This mindset needs to be built by Islamic education actors so that the services provided to users are no longer 
bureaucratic. Rhenald said, the characteristics of people with a corporate mindset are; first, not bound by time and place. It works not limited to hours and workspace. People like this have realized that time and place are no longer a barrier to work. Technology has turned it off. Humans today can be connected 24 hours a day, 7 days a week, without being bound by time and place. If the mindset is applied in the management of Islamic education institutions, an effective and efficient managerial sys tem will be formed. Furthermore, when drawn in the context of learning, the teacher will be more flexible and flexible in carrying out their duties and functions.

Second, to provide proactive services. Learning activities still concentrated on the transfer of knowledge fromthe teacher and confined in the classroom; it will be challenging to produce graduates who are highly competitive. The education paradigm has changed, no longer teacher-centered, but student centered. Teachers are required to be more proactive in providing facilities, guidance, and assis tance to students.

Third, not fixated on the budget.Unlike the mental bureaucrats that is all tied to costs (not working if there is no budget).People with a corporate mindset do not stop innovating because of money constraints. Fourth, maximizing the function of social media. Managers of Is lamic education today must be able to take advantage of the progress of available communication media. Social media is no longer justentertainment. He has transformed into a usefulcommunication tool, work aid, and ins piration in innovation. This opportunity must be able to be appropriately utilized.

Fifth, think solution when faced with a problem. Not busy think of reasons to save yourself. Sixth, not allergic to change. In the present era, change has become a necessity. An institution if it persists/is static in its management, will be defeated by an institution that has more dynamic management.

Moreover, seventh, think and act strategically. Steps in managing Is lamic education institutions must have a clear roadmap. The stated objectives must be realistic. Therefore, curriculum reorientation and the vision of primary Is lamic education to be carried out. Annual curriculum, vision, program, semester programs must be transparent, flexible, contextual, and futuristic.

Self-Driving. Organizations that are agile and dynamic in their adaptation wading through ocean disruption is an org anization that has HR (Human Resources) mentally good drivers (good drivers), not passengers ( passenger) (Kasali, 2017, pp. 16). With right driver mentality will want to open thems elves up, quickly and accurately read the situation, have integrity, be agile in acting, be aware of all bad possibilities, and can work effectively, innovatively and efficiently. These abilities are mainly needed by leaders and managers of Islamic education institutions. They are required to be reliable drivers for their institutions. Therefore, managerial competence alone is not enough. However, it must also be accompanied by the ability to lead while human minded passengers will tend to be bureaucratic, rigid, slow, and lacking in dis cipline.

Reshape or Create. There are genealogical thoughts that are popular among the Ummah Is lam which until now is still held firm. The genealogy is "keeping the old one good and taking the new one better." As much as mentioned above, that era 4.0 is an era where speed and ease become socialdemands. This indeed requires massive adjustments. Then there are two logical choices for Is lamic education to face this era, namely, reshape or create.

Reshape in the genealogy above means retaining the old ones well. However, in the era of 4.0 to maintain it was not enough, it must be sharpened. Old ways and systems that are still useful and relevant need to be modified following changes and times. For example at the level of management and professionalism of HR, it needs to be strengthened and enhanced by competence and capacity. It can be through training, seminars, workshops, study scholarships, and so on.

Another alternative is to create, create something entirely new or in the genealogy above "taking a new one better."This means that the old ways and systems are obsolete. So it is not possible to use it again. The only way out is to make an entirely new way and sy stem. For example, they are developing a new digital service system. So that citizens of Islamic education institutions can freely access all the needs related to education and adminis trative services. Another example, developing a contemporary learning model by fully utilizing digital technology, such as E-learning, Blended Learning, and so on.

\section{DISCUSSION, CONCLUSION AND RECOMMENDATIONS}

Is lamic education is education that is not only sufficient for knowledge and only becomes knowledge so that it only reaches cognitive knowledge. More than that, Is lamic education is an applied science, that is knowledge that must be followed up with understanding, appreciation and understanding of life that is able to deliver students in accordance with religious values. Is lamic education is an education system that can give a person to lead his life in accordance with the ideals of Is lam, because the values of Is lamhave animate and illustrate his personality

Entering this dis ruption era, Islamic education is required to be more sensitive to the symptoms of social change in society. Islamic education must be willing to disrupt itself if it is to strengthen its existence. Insisted on ways and the old systemand the shut down of the development of the world will increas ingly make Is lamic education increasingly worse and obsolete (obsolete).

Therefore, three things should be pursued by Is lamic education, changing the old mindset confined bureaucratic rules, into the dis ruptive mindset (dis ruptive mindset) that promote the corporative ways. Is lamic education must also do self-driving so that it can innovate according to the demands of the era of 4.0. Besides, Islamic education must also make reshape or create for all as pects in it to always be contextual to the demands and changes. 


\section{REFERENCES}

- Al-Djamali, M. \& Fadhil. (1967). Al-Tarbiyah al Insanal-jadid. Tunisia al-Syghly: Matba al-Ittihad al-'Aam.

- Amirudin, N. et. al. (2020). Implementation of Blended-Based Is lamic Education Learning. Journal of Critical Reviews, 7(8). DOI: $10.31838 /$ jer.07.08.456

- Amirudin, N. \& Basri, H. 2020. The Internalization of Is lamic Values on Undergraduate Students through the Battul Arqam. DAYAH: Journal ofIslamic Education,3(2). DOI: http://dx.doi.org/10.22373/jie.v3i2.7082

- Arifi, A. (2010). The Politics of Islamic Education Tracing Ideology and Actualization Islamic Education in the Flow of Globalization. Yogyakarta:Terrace.

- Arifin, M. (1987). Philosophy ofIslamic Education. Jakarta: Bina Aksara.

- Arifin, M. (2003). Islamic Education: Theoretical and Practical Review Based on the Interdisciplinary Approach. Jakarta:PT. Earth Literacy.

- Arikunto, S. (1998). Prosedur Penelitian Suatu Pendekatan Praktek. Jakarta:PT. Rineka Cipta.

- Asfaruddin, A. (2005, 11 12). The Philosophy of Islamic Education: Classical Views and M. Fethullah Gülen's Perspectives. Retrieved from https://fgulen.com: $\underline{\mathrm{https}: / / \mathrm{fgulen} . c o m / e n / g u l e n-m o v e m e n t / c o n f e r e n c e-p a p e r s / t h e-~}$ fethullah-gulen-movement-i/25504-the-philosophy-of-is lamic-education-classical-views-and-m-fethullahgulens-perspectives.

- Barizi, A. (Ed). (2011). Integrative Education Root of Tradition \& Scientific Integration Islamic education. Malang: UIN-Maliki Press.

- Dwiningrum, S. I. A. (2011). Decentralization and broad communityparticipation Education: A Theoretical and Empirical Study. Yogyakarta: Student Library.

- Eduaksi. Education4.0, What is it? 2018. https://eduaksi.com/pendidikan-4-0-apa/, accessed 11 February 2019 at 12.44 WIB.

- Hadi, S. (1989). Metode Research JilidI \& II. Yogyakarta: Andi Offset.

- Hamid, E. S. (2018). Disruptive Innovation: Benefits and Disadvantages Economic Development Context, https://law.uii.ac.id/wp-content/uploads/2017/07/2017-07-27-fh-uii-semnas-dis ruptive-innovation-faat-dankekurangi-dalam-economic-development-context-Edy-Suandi-Hamid.pdf, accessed February 11, 2019.

- Kasali, R. (2017). Disruption "Nothing Can Be Changed Before Facing Just Motivation Is Not Enough "Facing the Invisible Opponents of the Uber Civilization. Jakarta: PT Gramedia Main Library.

- Koentjaraningrat. (1989). Metode Penelitian Masyarakat. Jakarta: Gramedia Pustaka.

- Wis dom, S. (2007). Revitalizing Islamic Education. Yogy akarta: Graha Ilmu.

- Miles, B. M. \& Huberman, M. (1992). Analisis Data Kualitatif Buku Sumber Tentang Metode-Metode Baru. Jakarta:UIP.

- Mohammad, D. (2009) The Concept of Is lamic Education. Journal of Islamic Education.Volume 1.

- Moleong, L. J. (1996). Metode Penelitian Kualitatif. Bandung: Remaja Rosdakarya.

- Muhaiman. (2004). Islamic Education Paradigm. Bandung: PT. Teenager Rosdakarya.

- Muhadjir, N. (1996). Metode Penelitian Kualitatif. Yogyakarta: Rake Sarasin.

- Muhroqib. (2009). Islamic Education. Yogy akarta:LKiS.

- Rosidin. (2016). Islamic Education Problems in the Maqasid Shari'ah Perspective. Maraji ': Journal of Is lamic Studies.Vol.3, No. 1, hh. 186.

- Saputro, F. A. (2018). Mendikbud Reveals the Way to Face Revolution 4.0 in Education. https://www.republika.co.id/berita/pendidikan/eduaction/18/05/02/p8388c430-mendikbud- revealed- the way to deal with-revolusi-40-di-pendidikan. accessed Monday 11 February 2019.

- Suwardana, H. (2017). Industrial Revolution 4. 0 Based on Mental Revolution. JATI UNIQUE.Vol.1, No.2, hh. 102-110.

- Zuhairini. (2015). Philosophy ofIslamic Education. Jakarta:Bumi Aksara. 